\title{
Phenotypic plasticity in fish life-history traits in two neotropical reservoirs: Petit-Saut Reservoir in French Guiana and Brokopondo Reservoir in Suriname
}

\author{
Bernard de Mérona ${ }^{1}$, Jan $\mathrm{Mol}^{2}$, Régis Vigouroux ${ }^{3}$ and Paulo de Tarso Chaves ${ }^{4}$
}

Fish species are known for their large phenotypic plasticity in life-history traits in relation to environmental characteristics. Plasticity allows species to increase their fitness in a given environment. Here we examined the life-history response of fish species after an abrupt change in their environment caused by the damming of rivers. Two reservoirs of different age, both situated on the Guiana Shield, were investigated: the young Petit-Saut Reservoir in French Guiana (14 years) and the much older Brokopondo Reservoir in Suriname (44 years). Six life-history traits in 14 fish species were studied and compared to their value in the Sinnamary River prior to the completion of Petit-Saut Reservoir. The traits analyzed were maximum length, absolute and relative length at first maturation, proportion of mature oocytes in ripe gonad, batch fecundity and mean size of mature oocytes. The results revealed a general increase of reproductive effort. All species showed a decrease in maximum length. Compared to the values observed before the dam constructions, eight species had larger oocytes and three species showed an increased batch fecundity. These observed changes suggest a trend towards a pioneer strategy. The changes observed in Petit-Saut Reservoir also seemed to apply to the 30 years older Brokopondo Reservoir suggesting that these reservoirs remain in a state of immaturity for a long time.

Peixes são conhecidos pela grande plasticidade fenotípica com que respondem às características do meio, o que lhes permite aumentar as chances de sucesso frente a variações ambientais. No presente trabalho foram examinadas as respostas biológicas de teleósteos após uma abrupta modificação no ambiente provocada pelo represamento dos rios. Dois reservatórios de diferentes idades, situados no norte da América do Sul, foram investigados: um mais jovem (14 anos), Petit-Saut, na Guiana Francesa, e outro mais antigo (44 anos), Brokopondo, no Suriname. Em 14 espécies de peixes foram avaliados seis atributos biológicos, os quais foram comparados com a situação apresentada no rio Sinnamary antes do enchimento do Reservatório Petit-Saut. Avaliamos o tamanho máximo dos indivíduos, os comprimentos absoluto e relativo de primeira maturação, a proporção de ovócitos maduros em gônadas desovantes, a fecundidade por lote, e o tamanho médio dos ovócitos maduros. Os resultados indicam ter havido aumento do esforço reprodutivo com a formação dos reservatórios. Todas as espécies tiveram redução de tamanho. Comparados aos valores observados antes da formação dos reservatórios, oito espécies tiveram ovócitos maiores e três espécies mostraram aumento da fecundidade por lote. A constatação dessas mudanças aponta para a adoção de estratégias de ocupação pioneira. Aquelas observadas no Reservatório Petit-Saut parecem também aplicar-se ao Reservatório Brokopondo, 30 anos mais antigo, sugerindo que esses reservatórios mantêm-se em condição imatura por muito tempo.

Key words: South America, Reproduction, Strategy, Tactic, Fecundity, Oocyte size.

\footnotetext{
${ }^{1}$ IRD/LEHF, Université Cl. Bernard Lyon1, 43, Bd. du 11 nov. 1918, 69622, Villeurbanne Cedex, France. bernard.de-merona@univ-lyon1.fr ${ }^{2}$ University of Suriname, Center for Agricultural Research in Suriname CELOS, Department of Biology, P.O.B. 9212, Paramaribo, Suriname. fisheco@celos.sr.org

${ }^{3}$ Hydreco, B. P. 823, 97388 Kourou Cedex. vigouroux.regis@wanadoo.fr

[4Departamento de Zoologia, Universidade Federal do Paraná. Caixa Postal 19020, 81531-980 Curitiba, PR, Brazil. ptchaves@ufpr.br
} 


\section{Introduction}

The survival of a population in a given environment depends on the capacity of individuals to produce a number of descendants sufficient to maintain a viable population on the long term. Individuals develop reproductive traits characteristic of life-history tactics which are essentially compromises between immediate reproduction and growth (expected future reproduction) (Stearns, 1993). This process is determined by two main elements: (1) the constraint of the genetic background, and (2) adaptation to short-term variability of the environment (Stearns, 1993). The genetic background generates the life-history strategy of the species, whereas adaptation acts on its plasticity which defines its life-history tactic. Life-history strategies of species are the result of an evolutionary process involving long-term variability of the environment as stated by the "habitat templet” concept (Southwood, 1977; Southwood, 1988; Townsend \& Hildrew, 1994). Winemiller (1989, 1992) proposed three endpoints of life-history strategies for fish: seasonal, equilibrium and opportunist which are supposed to be associated with three broad types of environments (Winemiller, 1989, 1992; Winemiller \& Rose, 1992). The seasonal strategy characterized by late maturity, large fecundity and low juvenile survivorship would be associated with seasonal environments, the equilibrium strategy (low fecundity, high juvenile survivorship) would be associated with relatively stable environments and the opportunistic strategy (early maturation, low fecundity and low juvenile survivorship) with stochastic environments.

However, environments are subject to short-term changes and species have the capacity to adapt by adjusting some of their life-history traits in order to increase their fitness to the medium-term variability and heterogeneity of the habitat. Various studies show that most species develop different tactics in different environments. Latitude and/or habitat, in association with some environmental parameters, have been shown to have a significant impact on a number of traits (Bénech \& Niaré, 1994; Lobon-Cervia et al., 1997; Baker \& Foster, 2002; Mazzoni \& Iglesias-Rios, 2002; Gillespie \& Fox, 2003; Heins et al., 2004; Grover, 2005; Chapman et al., 2006; Danylchuk \& Tonn, 2006; Blanck \& Lamouroux, 2007; Duponchelle et al., 2007; Fox et al., 2007; Gomes Jr. \& Monteiro, 2007). However, these studies consider resident populations inhabiting different habitats for an unknown period of time. In that case it is possible that evolution took place and that genome modifications occurred.

Few studies deal with invasions, i.e., species which colonize a new environment by expanding their distribution area, or after artificial introduction, and these studies generate contradictory results (Baker \& Foster, 2002; Bøhn et al., 2004a; Dias et al., 2005).

Nevertheless, there are few data on the consequences of a rapid change in the environment, forcing every species to adapt rapidly (but see Lopes et al., 2000). The formation of artificial reservoirs constitutes a situation where the process of rapid adaptation of fish species can be observed.

Here we used data from two neotropical reservoirs of different ages situated in the same Guiana Shield biogeographical region. Brokopondo Reservoir in Suriname, the first large reservoir created in tropical rainforest is more than 44 years old, and Petit-Saut Reservoir in French Guiana is 14 years old. Some fish species occur in both reservoirs. A previous study conducted before the formation of the PetitSaut Reservoir has established the main life-history traits of fish species in the Sinnamary River (Ponton \& Mérona, 1998). Many of these species developed life-history tactics intermediate between the seasonal and the opportunistic endpoints strategies proposed by Winemiller, a fact which was related to the stochastic character of the river's hydrology. Generally, in agreement with Winemiller model, individuals in relatively stable lentic habitats are larger, mature later, and produce fewer and larger eggs, all traits associated with an equilibrium strategy, than those in running waters (Bénech \& Niaré, 1994; Baker \& Foster, 2002; Mazzoni \& Iglesias-Rios, 2002; Blanck \& Lamouroux, 2007). Thus, we hypothesized that the transformation of the largely unpredictable habitat of Sinnamary River into a more stable reservoir habitat would induce change of life-history traits towards the values characteristic of an equilibrium strategy.

In this study we aimed at 1) comparing the life-history traits of the dominant species in the Petit-Saut and Brokopondo Reservoirs to their values in the river Sinnamary before impoundment in order to evaluate the degree of plasticity of traits and to discuss the nature of the observed changes and 2) discussing possible interspecific differences in the change of traits.

\section{Material and Methods}

\section{Site description}

The Sinnamary River in French Guiana is $260 \mathrm{~km}$ long with a drainage area of $6363 \mathrm{~km}^{2}$ and a mean annual discharge of $230 \mathrm{~m}^{3} \cdot \mathrm{s}^{-1}$ (Tito de Morais \& Lauzanne, 1994). The climate in the region is tropical humid with a mean annual precipitation of about $3000 \mathrm{~mm}$ distributed in two rainy seasons: one short from mid-December to February and one long from April to July. The mean annual temperature varies between 25 and $26^{\circ} \mathrm{C}$ (Richard et al., 1997). In January 1994, a hydroelectric dam (Petit-Saut Dam) was closed in the lower part of the river approximately $60 \mathrm{~km}$ from the estuary (Fig. 1). The Petit-Saut Dam resulted in the inundation of more than $350 \mathrm{~km}^{2}$ of pristine tropical forest. The filling period lasted 16 months (Sissakian, 1997). The hydrological regime of the Sinnamary River follows a seasonal cycle with a low water season from July to October and a high water season from November to June. However, water level and discharge are also subjected to high daily and inter-annual variability. In the reservoir the oscillations of the water level are more regular with a maximum in June-July at about $35 \mathrm{~m}$ and a minimum between December and April at about 30 m (Fig. 2).

Brokopondo Reservoir is located on the middle course of 


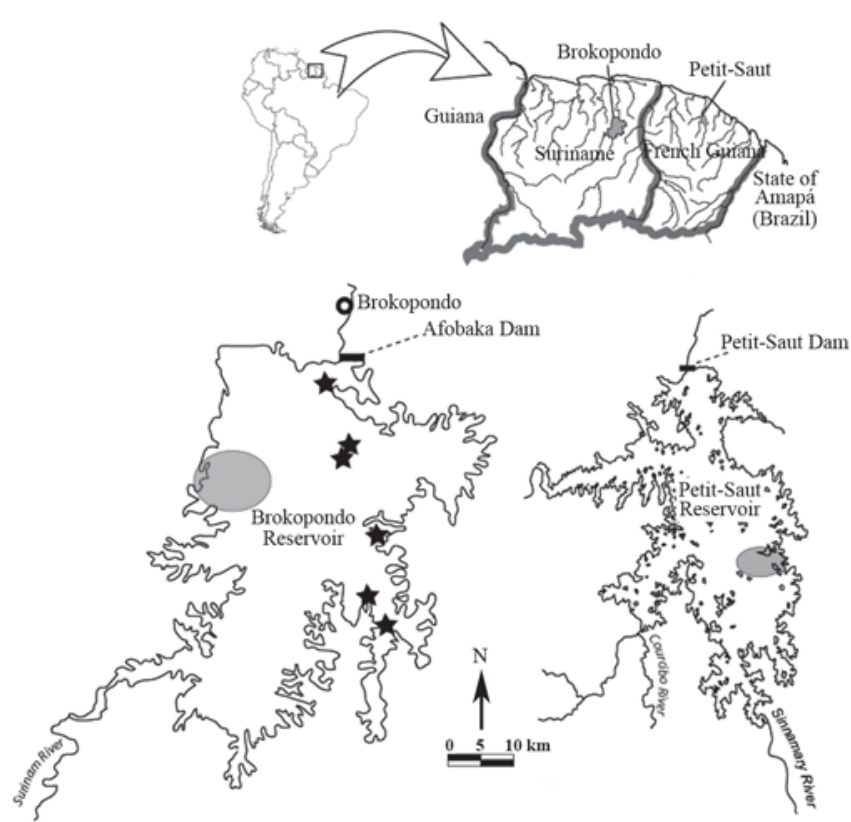

Fig. 1. Situation maps of the two reservoirs studied. Sampling areas are indicated by grey circles. Stars indicate additional samples in the Brokopondo Reservoir.

the Suriname River in Suriname. The Suriname River resembles Sinnamary River, but is larger (length $500 \mathrm{~km}$, drainage area $16500 \mathrm{~km}^{2}$, mean annual discharge $440 \mathrm{~m}^{3} \mathrm{~s}^{-1}$ ). The dam was constructed at the site Afobaka, $194 \mathrm{~km}$ from the estuary, and closed in February 1964 (Fig. 1). The filling lasted 4 years and resulted in the formation of a large reservoir of $1560 \mathrm{~km}^{2}$ (Heide, 1982). Basic data on the hydrology of the Suriname River and the Brokopondo dam are unavailable, however the drawdown was estimated to vary between 3 and $4 \mathrm{~m}$.

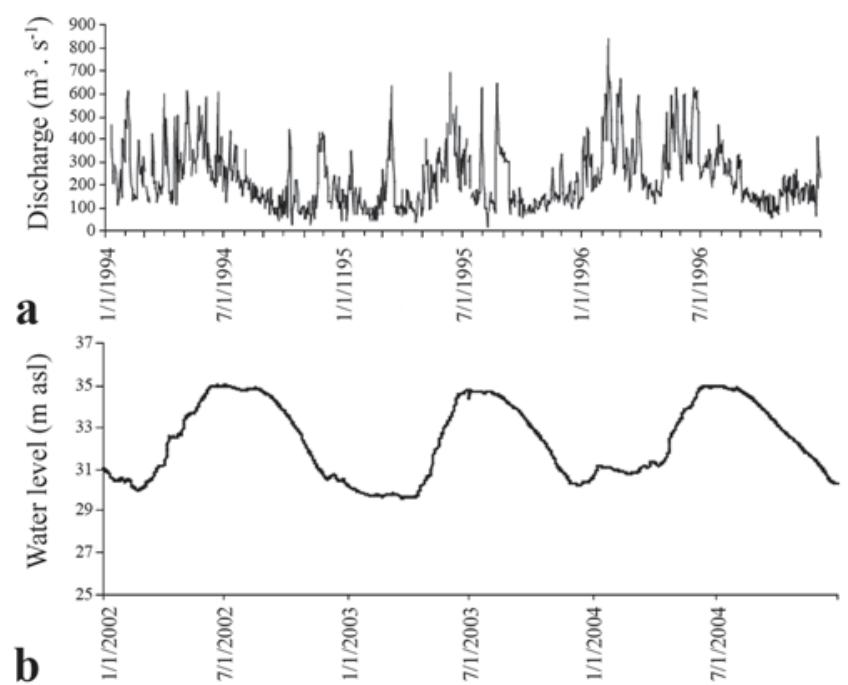

Fig. 2. (a) Daily variations of discharge at the entrance of Petit-Saut reservoir from January 1994 to December 1996. (b) Daily variations of water level in Petit-Saut Reservoir from January 2002 to December 2004. (asl = above sea level)

\section{Fish sampling}

We sampled fish from open waters with surface gillnets $25 \mathrm{~m}$ long by $2 \mathrm{~m}$ height of mesh size 10, 15, 20, 25, 30, 35, 40, 50, 60 and $70 \mathrm{~mm}$ between knots. Two sets of 10 gillnets were set at about 05:00 p.m. and removed at 07:00 a.m. the next day. Marginal habitats were sampled with PREDATOX ${ }^{\circledR}(6.6 \%$ emulsifiable solution of rotenone extracted from Derris elliptica by Saphyr, Antibes, France) at an approximate concentration of $3 \mathrm{mg} . \mathrm{l}^{-1}$.

Two periods were studied. The initial period took place in the three years following the closure of the Petit-Saut Dam, covering the entire filling phase of the reservoir. In that period, river samples were collected with gillnets in an area above the upper limit of the progression of inundation (1994-1995), and in 1996 in three stations localized at increasing distances upstream from the reservoir. The nets were positioned along the banks in areas of low water current. In the same period, rotenone collections were done in 1994 in 10 stations in the littoral zone of the reservoir in formation. The second period took place between 2002 and 2003. Fish communities of PetitSaut and Brokopondo reservoirs were sampled in the middle stretch of the reservoirs (Fig. 1). In Petit-Saut sampling was done every two months between January 2002 and May 2003. In Brokopondo sampling occurred in April, June, September, October, and December 2002 and in February 2003. One set of gillnets was placed in open waters and the other in marginal areas. Rotenone sampling took place in shallow habitats of the littoral zone.

\section{Specimen handling \& biological parameters studied}

Fish were identified at species level according to Planquette et al. (1996), Keith et al. (2000) and Le Bail et al. (2000). In Brokopondo Reservoir, the characid Bryconops affinis has been identified as B. melanurus (Mol et al., 2007). However careful examination of specimens from the two localities showed that it is the same species identified as $B$. affinis in Petit-Saut Reservoir (B. de Mérona, pers. obs.).

Every individual fish was measured (SL = standard length at $\mathrm{mm}$ ), and weighted ( $\mathrm{W}=$ individual weight at g). Sex and maturation stage of females were determined visually applying the following maturation scale: 1 - immature or not mature; 2 start of maturation; 3 - intermediate maturation; 4 - full maturity; 5 - active breeding. This scale was based on size, shape, volume, degree of vascularization and opacity of the ovaries and the size and appearance of oocytes in the ovary (Vazzoler, 1996).

A subset of gonads of different stages was fixed in Bouin fluid and the validity of the visual estimate of maturation was checked by microscopic examination of the gonad. We proceeded to 71 tests on 22 species. All but one confirmed the visual examination of the gonad or were conservative (females categorized stage 3 on the field proved to be in full maturation (stage 4) based on histology).

The gonads of stage 4 females were kept in Gilson's fluid (Bagenal \& Braum, 1968). After a minimal period of one month, the gonads were transferred to clear water and the oocytes separated from remaining connective tissues. For the river 
samples, the diameters of at least 100 wet oocytes were measured by using a dissecting microscope and an ocular micrometer. An evaluation of the proportion of oocytes to be laid in the next clutch was then obtained from the graphical representation of the size structure of these oocytes. The total number of oocytes per female was obtained either by using a dry gravimetric method and counting all the oocytes of two subsamples, or by counting all the oocytes when their number was less than 300 . The imprecision due to this method was less than $5 \%$. For the reservoir samples, all the oocytes separated by the Gilson treatment were spread in a Petri dish and a picture was taken by using a digital camera (Sony DSCS70). The picture was then analyzed by the free software Image (Wayne Rasband, National Institutes of Health, USA) for size structure of oocytes and total number of oocytes. Very large gonads were divided in part and separate pictures were taken. In these cases, the total number of oocytes was the sum of oocytes counted in every picture. These methods hardly identify pre-vitellogenic oocytes of very small size $(<100 \mathrm{~m})$ which are easily confounded with small debris and could also be washed by the rinsing process. In that way our results on fecundity are interpreted as the total number of oocytes potentially laid in a reproductive season and not as the total fecundity of the fish during its entire life.

Compatibility of the two methods was checked. Difference in the number of oocytes never exceeded the imprecision of method 1, and modal size of oocytes did not show significant difference although it was more precisely determined in method 2.

Six life-history traits were considered. (1) Maximum size (MSL) is the maximum observed standard length of females. (2) Size at first maturation (SL1M) is the standard length of the smallest female presenting and advanced stage of maturation (stages 4 or 5). (3) Relative size at first reproduction (RSL1M) is the ratio of SL1M to MSL. (4) The relative number of mature oocytes (\%MO) was calculated using the ratio: number of oocytes of the largest mode to total number of oocytes. (5) The mean number of oocytes potentially spawned per clutch (mean batch absolute fecundity $=$ MF). For the river samples MF was calculated by multiplying the total number of oocytes in each fully mature female by \%MO. For the reservoir samples MF was obtained directly by numbering the oocytes of the largest mode from the picture. (6) Mean oocyte diameter (MDO) was the mean of the diameter of oocytes of the largest mode in the ovary.

Due to the continuous nature of the reproduction of most fish species in the Sinnamary River, the size structure of populations does not show any mode progression and, as a consequence, we did not have information on the growth of species. However, we estimated the mean condition of populations, considering that a good condition is favorable to a rapid growth. To assess the condition factor of species (K), we first calculated for each species the linear regression between log-transformed variables W and SL. The slope b of the regression line was then used to calculate for each individual fish its condition factor, $\mathrm{K}=\mathrm{W} .10^{5} / \mathrm{SL}^{\mathrm{b}}$.

\section{Statistical treatments}

Differences of $\mathrm{K}$ between period and/or site were tested by a $t$ test.

It is well known that oocyte size and fecundity per batch are linked to the size and or the weight of the female. Thus, in order to detect statistical differences in egg size, fecundity and \%MO between periods, the general linear model was applied with the individual weight included in the model (1). The variables oocyte size and fecundity were log transformed in order to approximate normality.

$$
\text { Variable }=\mathrm{a} \text {. treatment }+\mathrm{b} \text {. weight }+\varepsilon
$$

\section{Results}

We were able to collect information on every life-history trait for 14 species which represent $85 \%$ of the total number of fishes captured in Petit-Saut Reservoir (Table 1). Only 6 of them were also present in Brokopondo Reservoir. Among these 14 species, five are Characidae, three Curimatidae, two Hemiodidae, one Anostomidae, one Acestrorhynchidae, one Auchenipteridae and one Loricariidae.

\section{Condition}

Six species (Acestrorhynchus microlepis, Bryconops affinis, Curimata cyprinoides, Hemiodus unimaculatus, Auchenipterus nuchalis and Cyphocharax spilurus) were in better condition in Petit-Saut Reservoir than in the river and one of them (B. affinis) also present in Brokopondo Reservoir showed a lower condition in the latter (Fig. 3). Five species did not show any tendency in the evolution of their condition (Bryconops caudomaculatus, Cyphocharax sp., Hypostomus gymnorhynchus, Hemiodus quadrimaculatus and Leporinus friderici), although the result concerning $H$. gymnorhynchus is questionable due to the low number of specimens in Sinnamary River. Finally, three species were apparently in a bad condition in Petit-Saut Reservoir as compared with Sinnamary River (Poptella brevispina, Charax pauciradiatus and Triportheus rotundatus). This bad condition was also observed in the Brokopondo Reservoir for P. brevispina.

\section{Maximum size and size at first maturation}

There was a general decreasing tendency in Maximum Standard Length during the ageing of the reservoirs (Table 2). However, some of the intra-specific differences between the two periods in Petit-Saut Reservoir are small as it is the case with C. cyprinoides (1.32\%), H. gymnorhynchus (2.63\%) and A. nuchalis (3.57\%). Moreover, for some species, the number of captured specimens was small (H. gymnorhynchus Sinnamary River, $P$. brevispina Brokopondo Reservoir) and, in that case, the determination of MSL is questionable.

No general pattern could be detected for the absolute and relative sizes at first maturation (Table 2). Seven species showed an increase in both traits in Petit-Saut Reservoir (in bold in Table 2) evidencing a delayed first reproduction, but two of them (A. microlepis and P. brevispina) had a lower size at first maturation in Brokopondo Reservoir. In the other 
Table 1. List of analyzed fish species with indication of their relative abundance in Petit-Saut Reservoir and of their diet from Mérona et al. (2003).

\begin{tabular}{llccc}
\hline \multicolumn{1}{c}{ Family } & \multicolumn{1}{c}{ Species } & Code & \% in capture & Diet \\
\hline Acestrorhynchidae & Acestrorhynchus microlepis (Jardine, 1841) & Amic & 4.19 & piscivore \\
Characidae & Bryconops affinis (Günther, 1864) & Baff & 1.96 & invertivore \\
& Bryconops caudomaculatus (Günther, 1864) & Bcau & 8.81 & invertivore \\
& Charax pauciradiatus (Günther, 1864) & Cpau & 6.55 & piscivore \\
& Poptella brevispina Reis, 1989 & Pbre & 3.21 & omnivore \\
& Triportheus rotundatus (Jardine, 1841) & Trot & 31.58 & omnivore \\
Hemiodontidae & Hemiodus unimaculatus (Bloch, 1794) & Heun & 4.28 & detritivore \\
& Hemiodus quadrimaculatus (Pellegrin, 1908) & Hqua & 5.21 & herbivore \\
Curimatidae & Curimata cyprinoides (Linnaeus, 1766) & Ccyp & 8.33 & detritivore \\
& Cyphocharax sp. & Cyp1 & 1.61 & detritivore \\
& Cyphocharax spilurus (Günther, 1864) & Cysp & 0.83 & detritivore \\
Anostomidae & Leporinus friderici (Bloch, 1794) & Lfri & 2.48 & herbivore \\
Auchenipteridae & Auchenipterus nuchalis (Spix \& Agassiz, 1829) & Anuc & 5.64 & invertivore \\
Loricariidae & Hypostomus gymnorhynchus (Norman, 1926) & Hgym & 0.67 & detritivore \\
\hline
\end{tabular}

species, size at maturity follows the decrease in maximum length, with changes in relative size depending on the amplitude of change in their maximum length.

\section{Oocyte size and batch fecundity}

In 8 species out of the 14 studied, the mean oocyte size increased in Petit-Saut Reservoir (Table 3, Fig. 4). However among these, only one species (A. microlepis) showed the same tendency in Brokopondo Reservoir. In the latter, B. affinis had smaller oocytes than in Sinnamary River. Three species showed an increase in fecundity in Petit-Saut Reservoir compared to its value in the river before damming (B. affinis, $C$. pauciradiatus and $P$. brevispina) and three other species showed the inverse tendency (C. cyprinoides, $H$. gymnorhynchus and T. rotundatus) (Table 3, Fig. 5). These changes in fecundity with ageing of reservoirs were confirmed for B. affinis, C. cyprinoides and P. brevispina in Brokopondo Reservoir. In this same reservoir, the fecundity of $A$. microlepis was highly increased.

In Petit-Saut Reservoir, six species showed a significant increase of the percentage of mature oocytes in the gonad (i.e., an increase in semelparity) whereas only one species showed the inverse tendency (A. nuchalis) and others did not change this trait (Table 3). The species also present in the Brokopondo Reservoir did not show the same pattern of variation; only A. microlepis increased its degree of semelparity.
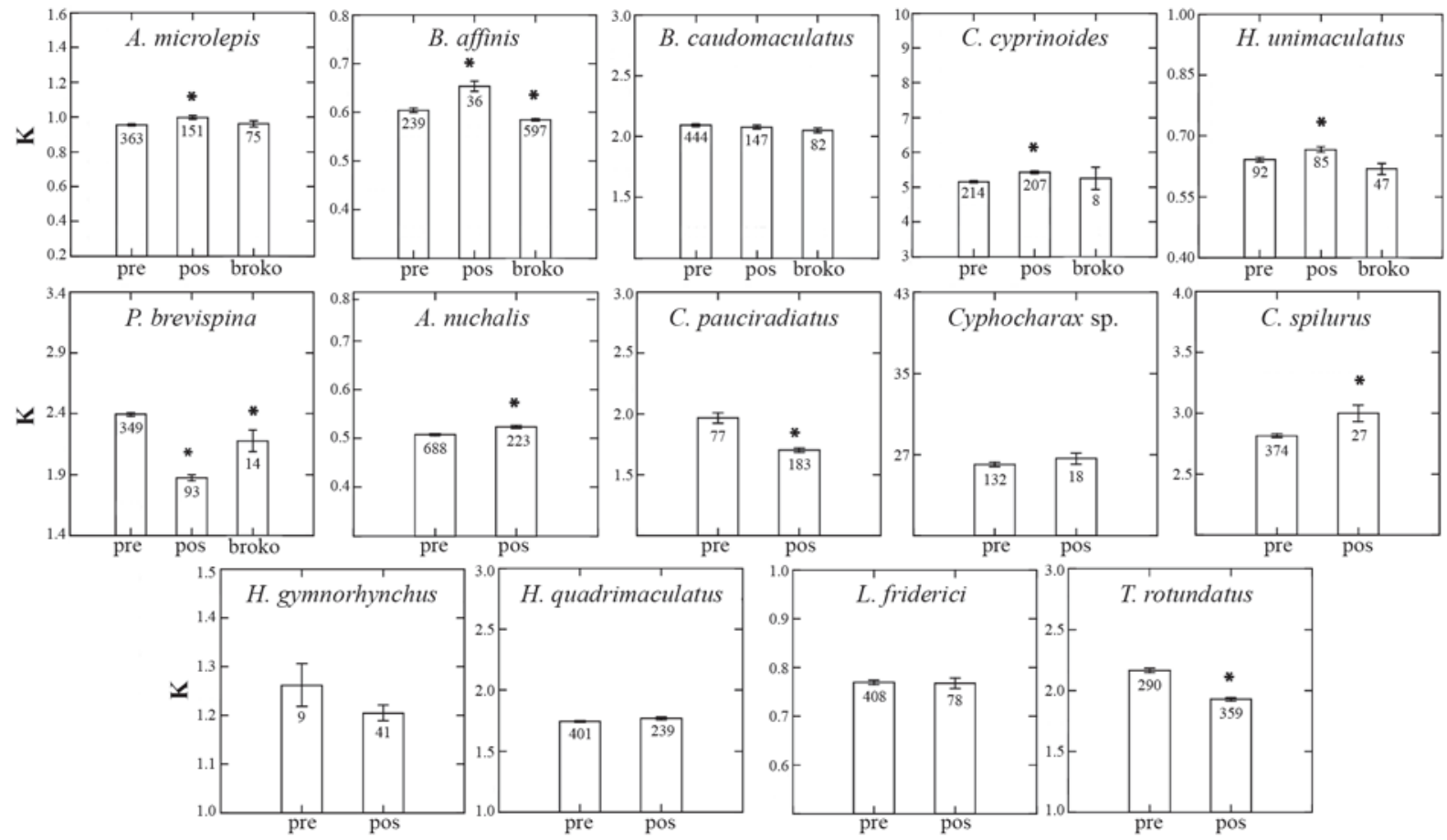

Fig. 3. Comparison of the condition factor of females of the 14 studied species in the different situations. pre $=$ Sinnamary River 1994-1996, pos = Petit-Saut Reservoir 2002-2003, broko = Brokopondo Reservoir 2002-2003. Stars indicate significant differences with the Sinnamary River by t test. The number of specimens used for the comparison appears inside the boxes. 
Table 2. Maximum standard length (MSL), size at first maturation (SL1M) and relative size at first maturation (RSL1M between brackets) in the different sampling sites and periods. “-” = not present.

\begin{tabular}{|c|c|c|c|c|c|c|c|c|c|}
\hline \multirow{2}{*}{ Species code } & \multicolumn{3}{|c|}{$\begin{array}{c}\text { Sinnamary River } \\
1994 / 1996\end{array}$} & \multicolumn{3}{|c|}{$\begin{array}{l}\text { Petit-Saut } \\
2002 / 2003\end{array}$} & \multicolumn{3}{|c|}{$\begin{array}{c}\text { Brokopondo } \\
2002 / 2003\end{array}$} \\
\hline & $\mathrm{n}$ & MSL & $\begin{array}{c}\text { SL1M } \\
\text { (RSL1M) }\end{array}$ & $\mathrm{n}$ & MSL & $\begin{array}{c}\text { SL1M } \\
\text { (RSL1M) }\end{array}$ & $\mathrm{n}$ & MSL & $\begin{array}{c}\text { SL1M } \\
\text { (RSL1M) }\end{array}$ \\
\hline Amic & 283 & 271 & $150(0.55)$ & 176 & 250 & $170(0.68)$ & 68 & 212 & $130(0.61)$ \\
\hline Anuc & 568 & 140 & $85(0.61)$ & 334 & 135 & $105(0.78)$ & - & - & - \\
\hline Baff & 165 & 122 & $90(0.73)$ & 42 & 111 & $95(0.86)$ & 272 & 100 & $60(0.60)$ \\
\hline Bcau & 403 & 125 & $80(0.64)$ & 160 & 116 & $70(0.60)$ & 75 & 100 & 65 (0.68) \\
\hline Ссур & 62 & 228 & $100(0.44)$ & 266 & 225 & $130(0.68)$ & 12 & 223 & $177(0.79)$ \\
\hline Сраu & 77 & 140 & $105(0.75)$ & 209 & 115 & 75 (0.65) & - & - & - \\
\hline Сур1 & 100 & 144 & $90(0.63)$ & 22 & 122 & $80(0.66)$ & - & - & - \\
\hline Cysp & 289 & 183 & $90(0.45)$ & 32 & 127 & 85 (0.67) & - & - & - \\
\hline Heun & 52 & 273 & $200(0.73)$ & 110 & 220 & $160(0.73)$ & 33 & 149 & $110(0.74)$ \\
\hline Hgym & 9 & 191 & $95(0.50)$ & 42 & 185 & $115(0.61)$ & - & - & - \\
\hline Hqua & 305 & 166 & $90(0.54)$ & 306 & 153 & $105(0.69)$ & - & - & - \\
\hline Lfri & 377 & 390 & $160(0.41)$ & 92 & 315 & $120(0.38)$ & - & - & - \\
\hline Pbre & 369 & 105 & $70(0.64)$ & 109 & 100 & $80(0.80)$ & 9 & 67 & $40(0.60)$ \\
\hline Trot & 452 & 255 & $160(0.63)$ & 564 & 226 & $130(0.63)$ & - & - & - \\
\hline
\end{tabular}

Table 3. Probabilities associated with the partial correlation of oocyte size, fecundity and percentage of mature oocytes in the gonad (\%MO) with site/period. Direction of change in parentheses. In column " $n$ " the first number is the number of observations from 1994/1996 and the second the number of observation from 2002/2003. "a” = observations on life-history traits of $H$. gymnorhynchus included specimens from the section downstream from the dam prior to dam closure.

\begin{tabular}{|c|c|c|c|c|c|c|c|c|}
\hline \multirow[t]{2}{*}{ Species code } & \multicolumn{4}{|c|}{$\begin{array}{c}\text { Sinnamary River 1994/1996 } \\
\text { vs. Petit-Saut Reservoir 2002-2003 }\end{array}$} & \multicolumn{4}{|c|}{$\begin{array}{c}\text { Sinnamary River 1994/1996 } \\
\text { vs.Brokopondo Reservoir 2002-2003 }\end{array}$} \\
\hline & $\mathrm{n}$ & Oocyte size & Fecundity & $\% \mathrm{MO}$ & $\mathrm{n}$ & Oocyte size & Fecundity & \%MO. \\
\hline Amic & $31 / 15$ & $0.004(+)$ & 0.337 & 0.823 & $31 / 20$ & $0.003(+)$ & $0.001(+)$ & $0.005(+)$ \\
\hline Anuc & $91 / 34$ & $0.001(+)$ & 0.061 & $0.047(-)$ & & & & \\
\hline Baff & $14 / 13$ & 0.572 & $0.004(+)$ & 0.653 & $14 / 35$ & $0.020(-)$ & $0.020(+)$ & 0.572 \\
\hline Bcau & $37 / 14$ & 0.270 & 0.150 & 0.266 & $37 / 18$ & 0.117 & 0.273 & 0.438 \\
\hline Ссур & $41 / 26$ & $<0.001(+)$ & $0.005(-)$ & $<0.001(+)$ & $41 / 7$ & 0.316 & $<0.001(-)$ & 0.249 \\
\hline Сур1 & $14 / 6$ & $<0.001(+)$ & 0.967 & 0.272 & & & & \\
\hline Cysp & $38 / 17$ & $0.013(+)$ & 0.236 & 0.967 & & & & \\
\hline Cpau & $30 / 13$ & $<0.001(+)$ & $0.006(+)$ & $<0.001(+)$ & & & & \\
\hline Heun & $9 / 27$ & $0.031(+)$ & 0.092 & $0.015(+)$ & $9 / 8$ & 0.147 & 0.269 & 0.432 \\
\hline Hgym & $24^{\mathrm{a}} / 20$ & 0.257 & $0.057(-)$ & 0.386 & & & & \\
\hline Hqua & $22 / 35$ & $<0.001(+)$ & 0.820 & $<0.001(+)$ & & & & \\
\hline Lfri & $18 / 12$ & 0.634 & 0.480 & 0.739 & & & & \\
\hline Pbre & $42 / 37$ & 0.128 & $<0.001(+)$ & $<0.001(+)$ & $42 / 12$ & 0.082 & $0.001(+)$ & 0.333 \\
\hline Trot & $60 / 33$ & 0.921 & $0.025(-)$ & $<0.001(+)$ & & & & \\
\hline
\end{tabular}

\section{Discussion}

All species investigated showed some plasticity in their life-history traits. This result is to be expected as the studied species were those which succeeded in adapting to the reservoir, an environment fundamentally different from the river where they used to live. For most species, significant differences were noted in egg size, batch fecundity or both. Only 2 species out of 14 studied showed difference only in their maximum size and/or the percentage of mature oocytes in the gonad. Intra-specific plasticity in life-history traits has been repeatedly reported in fish (Rochet, 2000; Heins et al., 2004; Blanck \& Lamouroux, 2007). The results of Rochet (2000) on marine families suggested that the plasticity of species is linked to the phylogeny. This does not seem to be a general tendency in our data. As an example, of the six studied species belonging to the Characidae family, 5 showed large variations in their traits whereas one did not.

The general tendency observed here was an increase in the reproductive effort. First, there was an overall decrease in the maximum size. This decrease could be the consequence of a slower growth and/or a decrease of the lifespan. Our data did not allow a control of growth. Indeed, in both the river and the reservoirs, fish species were almost continually in a reproductive state (B. de Mérona, pers. observ.), a behavior which rendered impracticable the study of mode progression. However fish condition could constitute an index of growth. Individual fishes with a good condition have enough resources for a rapid growth (Laffargue et al., 2007). Most of the species had a condition in the reservoir that was equal or superior to its value in the river. Reservoirs, and especially those in forested areas, offer food in abundance for fish. In two Brazilian reservoirs it has been shown that the mean weight of fish stomachs was significantly higher than in the river 

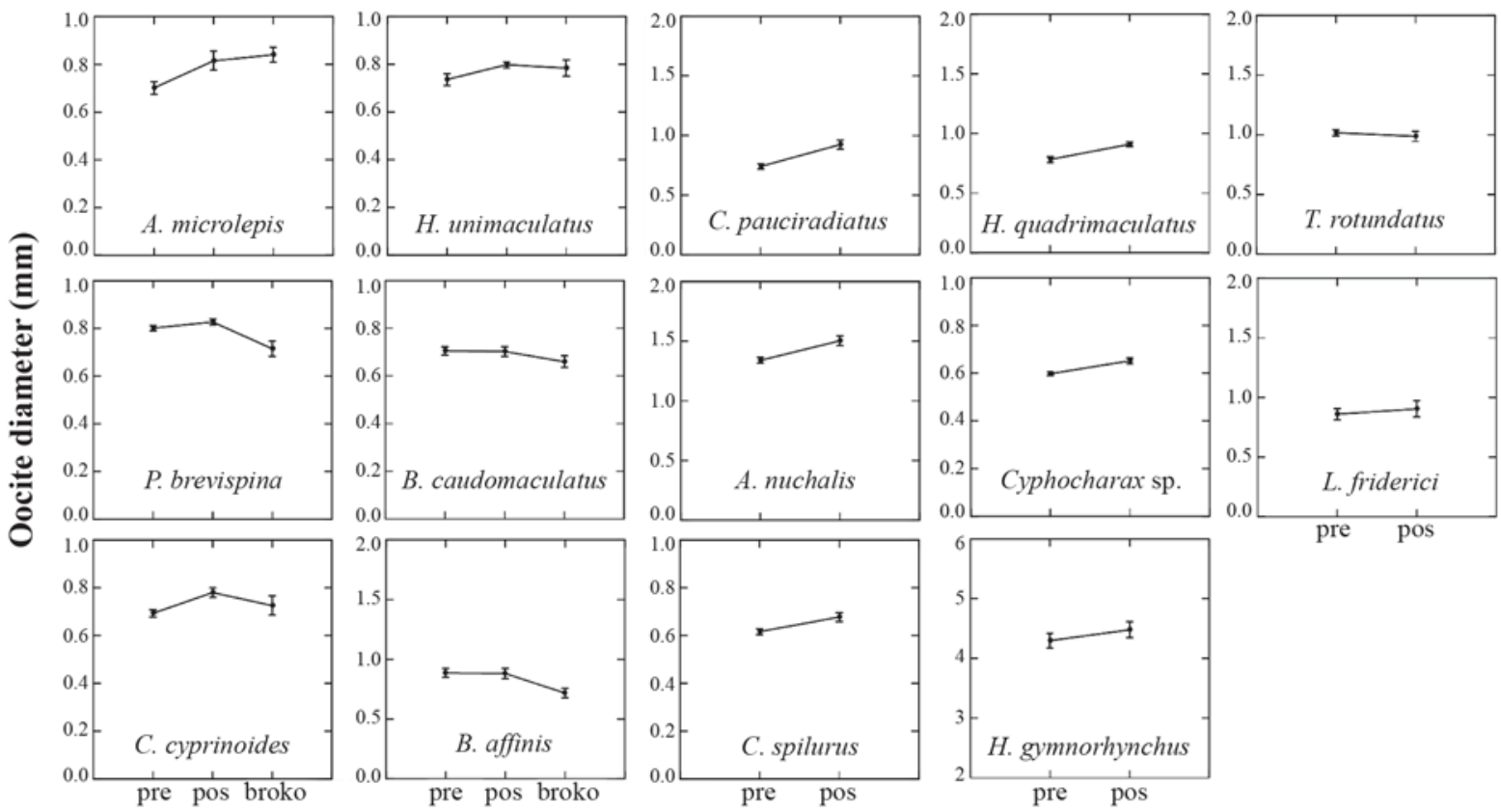

Fig. 4. Comparison of mean mature oocyte size of the 14 studied species in the different situations. pre = Sinnamary River 19941996, pos = Petit-Saut Reservoir 2002-2003, broko = Brokopondo Reservoir 2002-2003.
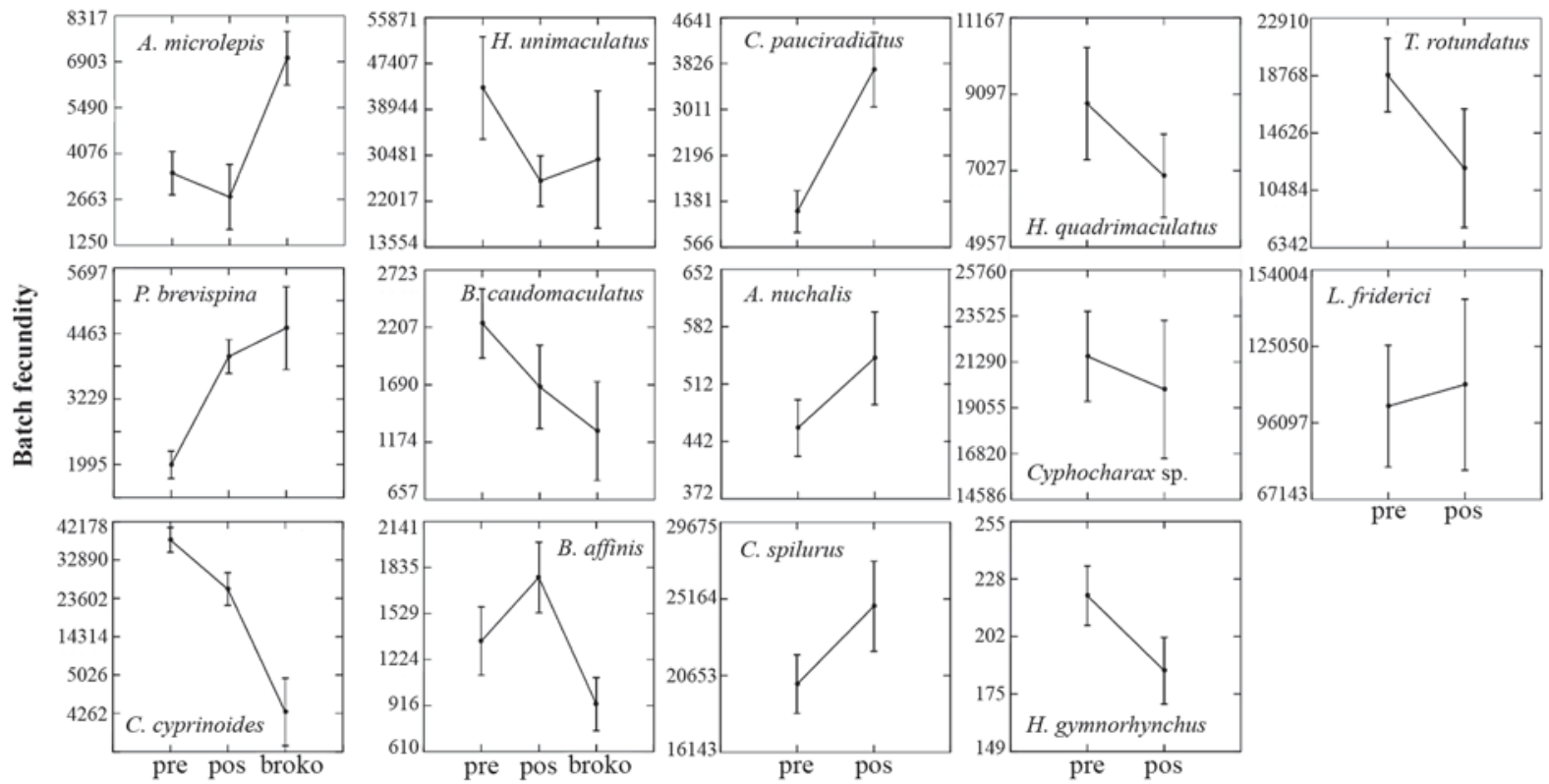

Fig. 5. Comparison of mean batch fecundity of the 14 studied species in the different situations. pre = Sinnamary River 19941996, pos = Petit-Saut Reservoir 2002-2003, broko = Brokopondo Reservoir 2002-2003.

prior to impoundment (Agostinho et al., 1999). Only 3 species out of 14 in Petit-Saut Reservoir and 2 out of 6 in Brokopondo Reservoir had a lower condition compared to that in Sinnamary River. Among these 3 species, two are omnivores and one is a piscivore. Generally omnivorous species, preadapted to consume a large variety of resources, are considered favored in the colonization phase of reservoirs (Agostinho et al., 2007). However, with the ageing of reservoirs, a specialization occurs and, as a consequence, omnivores lose their competitive advantage and their abundance declines (Mérona et al., 2003). These considerations suggest that, with the exception of the three species having low condition, the decrease in maximum size was the result of a decrease in longevity, a trait which has been shown negatively correlated to growth velocity (Metcalfe \& Monaghan, 2003). In other words, immediate reproduction 
is favored at the expense of expected future reproduction. This life-history tactic has been observed in some species that colonize a new environment (Bøhn et al., 2004). Nevertheless this pattern cannot be generalized as other studies describe the exact contrary, i.e., an increase of size following colonization of lentic environments by species preadapted to running waters (Bénech \& Niaré, 1994; Baker \& Foster, 2002).

Our results on the size of first maturation showed diversified specific responses to the change in environmental conditions, suggesting complex interactions between lifehistory traits. Because of a positive correlation between growth velocity and mortality (Pauly, 1980; Wootton, 1992) and a negative correlation between growth velocity and age at first maturation (Roff, 1984; Stearns \& Koella, 1986) we could expect a positive relation between longevity and age at maturity. In other terms the longer the life span, the more delayed is the first reproduction. Indeed early reproduction has an energetic cost which could limit later growth and longevity. Although we did not determine age at first reproduction, this hypothesis seems compatible with our data on half of the studied species which show a lower size at first maturation in the reservoirs than in the river. The opposite was observed in the seven other species with an increased size at first reproduction compared to its value before damming. This contradiction could be the expression of a tactic consisting of accumulating enough reserves to increase the amount of reproductive material available for the first reproduction event. There are some adaptive advantages linked to a rapid initial growth and/or an early reproduction. First, reaching rapidly a large body size can improve shortterm survival chance because this reduces the duration of the vulnerable period to predators. In addition, the amount of energy stored, being proportional to the weight, increases by a factor 3 with body size and allows higher resistance in periods of food shortage (Metcalfe \& Monaghan, 2003).

Like the size at first reproduction, mean oocyte size and batch fecundity did not show a consistent pattern of change across species. Most of the species showed an increase in one or both of these traits. Again, this result indicates an increase in the reproductive effort in the reservoirs for most of the species. For energetic and morphologic reasons, an inverse relationship is generally observed between oocyte size and batch fecundity (Elgar, 1990; Roff, 1992; Cambray \& Bruton, 1994; Heins et al., 2004 and many others). This relation was confirmed in two cases: C. cyprinoides in Petit-Saut Reservoir and B. affinis in Brokopondo Reservoir. Conversely two species experienced a parallel increase of these two traits (A. microlepis in Brokopondo Reservoir and C. pauciradiatus in Petit-Saut Reservoir) illustrating a large increase in reproductive investment.

The percentage of mature oocytes in the gonad, which measures the degree of semelparity, increased from the river to the reservoir situations for 6 species in Petit-Saut Reservoir. In some cases this increase in semelparity could explain the parallel increase in fecundity. This is an "all the eggs in the same basket" tactic, efficient in predictable environments. This tendency was observed in species with a very high fecundity. Given the large extent of the reproduction period in many fish species, this result may indicate that in these Guianese species not every female is necessarily involved in each reproduction event (Ponton \& Mérona, 1998). Conversely, A. nuchalis, a species with relatively large oocytes and low fecundity seemed to increase the number of bouts in a reproductive season.

One can imagine various hypotheses to explain why all species did not show the same evolution in their life-history traits.

A phylogenetic hypothesis would state that closely related species exhibit similar life-history strategies which constraint their plasticity and limit the options in adapting to new environments. For instance most of Characidae species studied by Winemiller (1989) were classified as seasonal or opportunistic/seasonal. Our data did not fit with that hypothesis. For example $P$. brevispina among the five Characidae studied, showed a similar reproductive strategy in Sinnamary River than the others characids (Ponton \& Mérona, 1998) but reacted in a different way to the colonization of the reservoir. Similarly, C. cyprinoides lowered its batch fecundity in the reservoirs whereas the two other species of Curimatidae did not change this trait. However, the limited set of data analyzed here prevents the generalization of this conclusion. As an example, iteroparity is a shared trait among the two Auchenipteridae present in Sinnamary River (Ponton \& Mérona, 1998). The genetic background of these species could prevent a change towards an increase of semelparity even if such a change is adaptive.

A trophic hypothesis would suggest that species have different capacities to accumulate energy for growth and reproduction depending on their diet (Chigbu \& Sibley, 1994). Again, this was not verified in our data as species with similar diets did not react in the same way for their reproductive tactics.

Finally, a competition hypothesis would interpret betweenspecies differences by a tendency for species to avoid competition. It is well known that life-history tactics result in trade-offs between costs and benefits and that, in the medium term, different tactics could be equally adapted to the variability of the environment. In that way species could adopt slightly different tactics which lower the degree of competition.

The changes observed did not seem to conform to the predictions of Winemiller's model. Given that reservoirs represent a much more stable and predictable environment than rivers, we expected a trend towards traits more characteristic of an equilibrium strategy. This expectation was founded on observations from inter and intraspecific studies evidencing larger size, longer longevity, larger eggs, lower fecundity, in lentic environments compared to lotic ones (Winemiller, 1989; Mazzoni \& Iglesias-Rio, 2002; Blanck \& Lamouroux, 2007). Moreover a recent study of the fish assemblage of West African rivers showed an increase in the 
proportion of equilibrium strategists with the hydrological stability of the drainage basins (Tedesco et al., 2008). In contradiction with these previous observations, species in Petit Saut and Brokopondo reservoirs tend to adopt reproductive tactics combining traits of the three endpoints strategies proposed by Winemiller (1992). An early maturation and small size is typical of opportunistic species, high fecundity of seasonal species and large oocytes of equilibrium strategists. The changes in reproductive tactics observed in the reservoir fishes were more similar with a pioneer strategy of invasive species (Rosecchi et al., 2001; Bøhn et al., 2004; Olden et al., 2006; Garcia-Berthou, 2007; McPhee, 2007). It is worth noting that the tendencies observed in Petit-Saut Reservoir also seemed to apply to the 30 years older Brokopondo Reservoir. This observation suggests that these reservoirs stay in a state of immaturity for a long time. Compared to natural lakes, reservoirs maintain much closer relationships with their inlet rivers. We need to learn more about the way fish species in reservoirs use the upstream river for their reproduction in order to fully explain this longterm pioneer strategy.

\section{Acknowledgements}

This research was supported by Eléctricité de France (EDF). Special thanks for their assistance in field work to Shamita Shadew and Paul Ouboter in Surinam, and to Laurent Guillemet and Roland Aboikoni in French Guiana. The authors are also grateful to two anonymous referees for their help in improving the manuscript.

\section{Literature Cited}

Agostinho A. A., L. C. Gomes \& F. M. Pelicice. 2007. Ecologia e manejo de recursos pesqueiros em reservatórios do Brasil. Maringá, Eduem, 501p.

Agostinho A. A., L. E. Miranda, L. M. Bini, L. C. Gomes, S. M. Thomaz \& H. I. Suzuki. 1999. Patterns of colonization in neotropical reservoirs, and prognoses on aging. Pp. 227-265. In: Tundisi J. G. \& M. Straskraba (Eds.). Theoretical Reservoir Ecology and its Applications. São Carlos, International Institute of Ecology; Leiden, The Netherlands, Backhuys Publishers; Rio de Janeiro, Brazilian Academy of Sciences, 585p.

Bagenal, T. B. \& E. Braum. 1968. Egg and life history. Pp. 159-181. In: Ricker, W. E. (Ed.). Methods for Assessment of Fish Production in Fresh Waters. Oxford, Blackwell, IBP Handbook 3, 427p.

Baker, J. A. \& S. A. Foster. 2002. Phenotypic plasticity for life history traits in a stream population of the threespine stickleback, Gasterosteus aculeatus L. Ecology of Freshwater Fish, 11(1): 20-29.

Blanck, A. \& N. Lamouroux. 2007. Large-scale intraspecific variation in life-history traits of European freshwater fish. Journal of Biogeography, 34(5): 862-875.

Bénech, V. \& T. Niaré. 1994. Modifications du milieu et expressions de la stratégie adaptative de Brycinus leuciscus (Characidae) dans le bassin du Niger. Revue d'Hydrobiologie Tropicale, 27(2): 173-183.
Bøhn, T., O. Terje Sandlund, P.-A. Amundsen \& R. Primicerio. 2004. Rapidly changing life history during invasion. Oikos, 106(1): 138-150.

Cambray, J. A. \& M. N. Bruton. 1994. Evolutionary trade-off between egg size and egg number in a sister species pair of redfin minnows, Pseudobarbus afer and P. asper (Osteichthyes, Cyprinidae). Ichthyological Exploration of Freshwaters, 5(4): 305-320.

Chapman, A., D. L. Morgan, S. J. Beatty \& H. S. Gill. 2006. Variation in life history of land-locked lacustrine and riverine populations of Galaxias maculatus (Jenyns 1842) in Western Australia. Environmental Biology of Fishes, 77(1): 21-37.

Chigbu, P. \& T. H. Sibley. 1994. Relationship between abundance, growth, egg size and fecundity in a landlocked population of longfin smelt, Spirinchus thaleichthys. Journal of Fish Biology, 45(1): 1-15.

Danylchuk, A. J. \& W. M. Tonn. 2006. Natural disturbance and life history, consequences of winterkill on fathead minnow in boreal lakes. Journal of Fish Biology, 68(3): 681-394.

Dias, R. M., D. Bailly, R. R. Antônio, H. I. Suzuki \& A. A. Agostinho. 2005. Colonization of the Corumbá Reservoir (Corumbá River, Paraná River Basin, Goiás State, Brazil) by the "lambari” Astyanax altiparanae (Tetragonopterinae; Characidae ). Brazilian Archives of Biology and Technology, 48(3): 467-476.

Duponchelle, F., F. Lino, N. Hubert, J. Panfili, J.-F. Renno, E. Baras, J. P. Torrico, R. Dugue \& J. Nuñez. 2007. Environmentrelated life-history trait variations of the red-bellied piranha Pygocentrus nattereri in two river basins of the Bolivian Amazon. Journal of Fish Biology, 71(4): 1113-1134.

Elgar, M. A. 1990. Evolutionary compromise between a few large and many small eggs, comparative evidence in teleost fish. Oikos, 59: 283-287.

Fox, M. G., A. Vila-Gispert \& G. H. Gopp. 2007. Life-history traits of introduced Iberian pumpkinseed Lepomis gibbosus relative to native populations. Can differences explain colonization success? Journal of Fish Biology, 71(Suppl. D): 56-69.

Garcia-Berthou, E. 2007. The characteristics of invasive fishes, what has been learned so far? Journal of Fish Biology, 71(Suppl. D): 33-55.

Gillespie, G. J. \& M. G. Fox. 2003. Morphological and life-history differentiation between littoral and pelagic forms of pumpkinseed. Journal of Fish Biology, 62(5): 1099-1115.

Gomes Jr., J. L. \& L. R. Monteiro. 2007. Size and fecundity variation in populations of Poecilia vivipara Block \& Schneider (Teleostei; Poeciliidae) inhabiting an environmental gradient. Journal of Fish Biology, 71(6): 1799-1809.

Grover, M. C. 2005. Changes in size and age at maturity in a population of kokanee Oncorhynchus nerka during a period of declining growth conditions. Journal of Fish Biology, 66(1): 122-134.

Heide, J. van der. 1982. Lake Brokopondo. Filling phase limnology of a man-made lake in the humid tropics. Alblasserdam, The Netherlands, Kanters, 427p.

Heins, D. C., J. A. Baker \& J. M. Guill. 2004. Seasonal and interannual components of intrapopulation variation in clutch size and egg size of a darter. Ecology of Freshwater Fish, 13(4): 258-265.

Keith, P., P. Y. Le Bail \& P. Planquette. 2000. Atlas des poissons d'eau douce de Guyane. Tome 2. Fasc. 1. Collection Patrimoines Naturels, 43(I). Paris, M.N.H.N./S.P.N., 286p. 
Laffargue, P., F. Lagardère, A. D. Rijnsdorp, A. Fillon \& R. Amara. 2007. Growth performances of juvenile sole Solea solea under environmental constraints of embayed nursery areas. Aquatic Living Resources, 20: 213-221.

Le Bail, P.-Y., P. Keith \& P. Planquette. 2000. Atlas des poissons d'eau douce de Guyane. Tome 2. Fasc. 2. Collection Patrimoines Naturels, 43(II). Paris, M.N.H.N./S.P.N., 307p.

Lobón-Cerviá, J., C. G. Utrilla, P. A. Rincon \& F. Amezcua. 1997. Environmentally induced spatio-temporal variations in the fecundity of brown trout Salmo trutta L.: trade-offs between egg size and number. Freshwater Biology, 38(2): 277-288.

Lopes, C. de A., E. Benedito-Cecilio \& A. A. Agostinho. 2000. The reproductive strategy of Leporinus friderici (Characiformes, Anostomidae) in the Paraná River Basin, the effect of reservoirs. Revista Brasileira de Biologia, 60(2): 255-266.

Mazzoni, R. \& R. Iglesias-Rios. 2002. Environmentally related life history variations in Geophagus brasiliensis. Journal of Fish Biology, 61(6): 1606-1618.

McPhee, M. V. 2007. Age, growth, and life-history comparisons between the invasive white sucker (Catostomus commersoni) and native Rio Grande sucker (C. plebeius). The Southwestern Naturalist, 52(1): 15-25.

Mérona B. de, R. Vigouroux \& V. Horeau. 2003. Changes in food resources and their utilization by fish assemblages in a large tropical reservoir in South America (Petit-Saut Dam, French Guiana). Acta Oecologica, 24: 147-156.

Metcalfe, N. B. \& P. Monaghan. 2003. Growth versus lifespan, perspectives from evolutionary ecology. Experimental Gerontology, 38(9): 935-940.

Mol, J. H., B. de Mérona, P. E. Ouboter \& S. Sahdew. 2007. The fish fauna of Brokopondo Reservoir, Suriname, during 40 years of impoundment. Neotropical Ichthyology, 5(3): 351-368.

Olden, J. D., N. LeRoy Poff \& K. R. Bestgen. 2006. Life-history strategies predict fish invasions and extirpations in the Colorado River Basin. Ecological Monographs, 76: 25-40.

Pauly, D. 1980. On the interrelationships between natural mortality, growth parameters, and mean environmental temperature in 175 fish stocks. Journal du Conseil International pour l'Exploitation de la Mer, 39: 175-192

Planquette, P., P. Keith \& P.-Y. Le Bail. 1996. Atlas des poissons d'eau douce de Guyane. Tome 1. Collection Patrimoines Naturels, 22. Paris, M.N.H.N./S.P.N., 429p.

Ponton, D. \& B. de Mérona. 1998. Fish Life-history tactics in a neotropical river with a highly stochastic hydrological regime, the Sinnamary River, French Guiana, South America. Polskie Archiwum Hydrobiologii, 45: 201-224.

Richard, S., A. Arnoux \& P. Cerdan. 1997. Evolution de la qualité physico-chimique des eaux de la retenue et du tronçon aval depuis le début de la mise en eau du barrage de Petit-Saut. Hydroécologie Appliquée, 9: 57-84.

Rochet, M.-J. 2000. A comparative approach to life-history strategies and tactics among four orders of teleost fish. ICES Journal of Marine Science, 57(2): 228-239.

Roff, D. A. 1984. The evolution of life history parameters in teleosts. Canadian Journal of Fisheries and Aquatic Sciences, 41: 9891000

Roff, D. A. 1992. The evolution of life histories, theory and analysis. New York, Chapman \& Hall, 535p.

Rosecchi, E., F. Thomas \& A. J. Crivelli. 2001. Can life-history traits predict the fate of introduced species? A case study on two cyprinid fish in southern France. Freshwater Biology, 46: 845-853.
Sissakian, C. 1997. Présentation générale de l’aménagement hydroélectrique de Petit-Saut (Guyane française) et du programme de suivi écologique lié à sa mise en eau. Hydroécologie Appliquée, 9: 1-22.

Southwood, T. R. E. 1977. Habitat, the templet for ecological strategies? Journal of Animal Ecology, 46: 337-365.

Southwood, T. R. E. 1988. Tactics, strategies and templets. Oikos, 52: 3-18.

Stearns, S. C. 1993. The evolution of life histories. Oxford, New York, Tokyo, Oxford University Press, 249p.

Stearns, S. C. \& J. Koella. 1986. The evolution of phenotypic plasticity in life-history traits, predictions for norms of reaction for age- and size-at-maturity. Evolution, 40: 893-913.

Tedesco, P. A., B. Hugueny, T. Oberdorff, H. H. Dürr, S. Mérigoux \& B. de Mérona. 2008. River hydrological seasonality influences life history strategies of tropical riverine fishes. Oecologia, 156: 691-702.

Tito de Morais L. \& L. Lauzanne. 1994. Zonation longitudinale des peuplements ichtyques avant mise en eau de la retenue de PetitSaut (Guyane française). Revue d'Hydrobiologie Tropicale, 27(4): 467-483.

Townsend, C. R. \& A. G. Hildrew. 1994. Species traits in relation to a habitat templet for river systems. Freshwater Biology, 31: 265-275.

Vazzoler A. E. A. de M. 1996. Biologia da reprodução de peixes teleósteos, teoria e prática. Maringá, Eduem, 169p.

Winemiller, K. O. 1989. Patterns of variation in life history among South American fishes in seasonal environments. Oecologia, 81: 225-241.

Winemiller, K. O. 1992. Life-history strategies and the effectiveness of sexual selection. Oikos, 63: 318-327.

Winemiller, K. O. \& K. A. Rose. 1992. Patterns of Life-History diversification in North American fishes, implications for population regulation. Canadian Journal of Fisheries and Aquatic Science, 49: 2196-2218.

Wootton, R. J. 1992. Constraints in the evolution of fish life histories. Netherlands Journal of Zoology, 42: 291-303.

Accepted August 28, 2009 Published December 18, 2009 